\title{
INVESTIGATING THE EFFECT OF TURKEY'S HIGH-TECH EXPORTS ON THE ECONOMIC GROWTH USING THE STRUCTURAL BREAK ARDL BOUNDS TESTING
}

\author{
TÜRKIYE’DE YÜKSEK TEKNOLOJI İHRACATININ İKTISSADİ BÜYÜMEYE \\ ETKİSININ YAPISAL KIRILMALI ARDL SINIR TESTİ İLE İNCELENMESİ
}

\begin{abstract}
Şerif CANBAY ${ }^{1}$
Abstract

While the technological capacity and efforts of developed and some developing countries as a result of R\&D activities position these countries among the high-technology product exporting countries, it is seen that developing countries that don't have adequate technological infrastructure and don't attach importance to $R \& D$ activities are among the countries that import technology and high technology products at higher costs. The technological knowledge and skills discovered as a result of the increase in the intensity of R\&D activities affect economic growth positively by leading to new high-tech products purchased in international markets.

This study aims to investigate the relationship between Turkey's high-tech exports economic growth. For this purpose, ARDL bounds testing was carried out to predict the relationships between the variables using the data on high-tech exports and GDP variables of Turkey for the 1989-2016 period. As a result of the analysis, it was found that a $1 \%$ increase in high technology exports increased the economic growth by approximately $0.44 \%$ in the long term.
\end{abstract}

Keyword: Economic Growth, High-tech Exports, Research and Development (R\&D), Innovation, ARDL Bounds Testing

JEL Classification: F14, F43, N70, O30, O10

\section{Öz}

Gelişmiş ve bazı gelişmekte olan ülkelerin Ar-Ge faaliyetleri neticesinde elde ettikleri teknolojik kapasite ve çabalar, bu ülkeleri yüksek teknolojili ürün ihracatçısı ülkeler arasına sokarken, yeterli teknolojik alt yapıya sahip olamayan ve Ar-Ge faaliyetlerine yeterli önemi vermeyen/veremeyen çoğu gelişmekte olan ülkede ise yüksek maliyetlerle teknoloji ve yüksek teknolojili ürün ithal eden ülkeler içerisinde oldukları görülmektedir. Ar-Ge faaliyetlerinin yoğunluğunun artması neticesinde keşfedilen teknolojik bilgi ve yetenek ekonominin tümüne yayılması, yeni yüksek teknolojili ürünleri ortaya çıkartması ve bu ürünlerin uluslararası pazarlarda alıcı bulması suretiyle iktisadi büyümeyi olumlu yönde etkilemektedir.

Bu çalışmada Türkiye'nin yüksek teknoloji ihracatı ile iktisadi büyüme arasındaki ilişkilerin incelenmesi amaçlanmıştır. Bu amaç doğrultusunda Türkiye'nin 1989-2016 dönemi için yüksek teknolojili ürün ihracatı ile GSYİH değişkenlerine ait veriler kullanılarak ARDL sınır testi yapılmış ve değişkenler arasındaki ilişkiler tahmin edilmeye çalışılmıştır. Yapılan analiz sonucunda uzun dönemde yüksek teknoloji ihracatında görülen \%1'lik artışın iktisadi büyümeyi yaklaşık \%0.44 oranında artırdığı tespit edilmiştir.

Anahtar Kelimeler: İktisadi Büyüme, Yüksek Teknoloji İhracatı, Araştırma ve Geliştirme, İnovasyon, ARDL Sinır Testi

JEL Sinıflandırması: F14, F43, N70, O30, O10

\footnotetext{
${ }^{1}$ Dr.Öğr.Üyesi, Düzce Üniversitesi Akçakocabey Siyasal Bilgiler Fakültesi, serifcanbay@ duzce.edu.tr,

Orcid: 0000-0001-6141-7510
} 


\section{INTRODUCTION}

The economic growth of a country depends on many factors. Especially in the early 1980s, many of the developing countries have made regulations to implement export-oriented growth strategies, one of these factors. Since then, the relationship between exports and economic growth has become a significant issue for all countries and has been one of the most studied economic topics in the literature.

To be able to escape the middle-income trap and to provide a competitive advantage in international trade, a country needs to be able to produce the products with the advanced and latest technology beyond its natural resources. Classical and Neoclassical economists have assumed that technological progress is exogenous to economic growth. Solow, who contributed significantly to the theory of economic growth with his model, was also considering technological progress as an exogenous factor to economic growth (Solow, 1956:66). As a result of his study conducted with US data, Solow (1957:312) argued that technology has increased economic growth. Romer, one of the founders of Research and Development (R\&D) based Endogenous Growth Models, has also argued that the R\&D-based technological development increased the economic growth and productivity (Romer, 1990:71; 1986:1002). Lucas, however, claimed that industries producing high-tech goods accelerated human capital accumulation (Lucas, 1988:27-28). All these results show that the countries producing technologically advanced products become superior to their competing countries, and increase the production level and quality (Sylwester, 2001:72).

In today's world, the competitiveness among countries has become connected to the high technology content of the goods and services they produce. For this reason, the struggle in the advanced technology-based industries has turned into a struggle for existence (Baumol, 2002:23). In the world that is in the process of constant change and development with the advances in technology, however, ensuring competitiveness against other countries and maintaining the struggle for existence is only possible by countries' resilience to this change. Furthermore, the primary source for this change necessary for the struggle for existence is the $R \& D$ activities. The significance of $R \& D$ activities lies in the resulting innovation and new technologies that penetrate the whole economy. There is strong evidence that the innovation and technology that emerge as a result of $\mathrm{R} \& \mathrm{D}$ activities lead to the increase in exports, capital accumulation and economic growth of the country by bringing high value-added products, especially high-tech products. Most of the researchers investigating the differences in economic growth rates between countries state that the level of $R \& D$ activities of countries and the levels of technological knowledge directly affect their economic growth performance. While the technological capacity and efforts of developed and some developing countries as a result of $\mathrm{R} \& \mathrm{D}$ activities position these countries among the high-technology product exporting countries, it is seen that developing countries that do not have adequate technological infrastructure and doesn't attach importance to R\&D activities are among the countries that import technology and high technology products at higher costs. The technological knowledge and skills discovered as a result of the increase in the intensity of R\&D activities affect economic growth positively by leading to new high-tech products purchased in international markets.

In this study, it was aimed to investigate the effect of Turkey's exports of high-tech products on economic growth. For this purpose, firstly, a literature review was made on the subject. Then the relationship between high technology product exports and economic growth in the 1989-2016 period, was examined using time series analysis. 


\section{LITERATURE REVIEW}

The failure of import-substitution strategies started to boost economic growth in the 1970s has led to discussions about the possible contribution of exports to economic growth. Moreover, all these discussions have resulted in numerous empirical studies to test the exportbased growth hypothesis. While some of these studies support the export-led growth hypothesis, others put forth the findings that do not support this hypothesis.

Some of the studies supporting the export-led growth hypothesis conducted by Tyler (1981), Kavoussi (1984), Rivera-Batiz and Romer (1991), Grossman (1991), Serletis (1992), Bahmani-Oskooee and Alse (1993), Sengupta and Espana (1994), Kwan and Kwok (1995), Doraisami (1996), Ghatak et al. (1997), Ekanayake (1999), Al-Yousif (1999), BahmaniOskooee and Niroomand (1999), Anwer and Sampath (2000), Ramos (2001), Vohra (2001), Medina-Smith (2001), Keong and Live (2003), Awokuse (2003), Yusop and Liew (2003), Abual-Foul (2004), Abou-Stait (2005), Shirazi and Abdul Manap (2005), Mamun and Nath (2005), Pandey (2006), Eusuf and Ahmed (2007), Ullah et al. (2009), Elbeydi et al. (2010), Jarra (2013), Yardımcıoğlu and Gülmez (2013), Istaiteyeh and Ismail (2015), Saleem and Sial (2015). Some of the studies in Turkey supporting the export-led growth hypothesis have been conducted by Kızılgöl (2006), Taban and Aktar (2008), Halıcıoğlu (2007), Bilgin and Şahbaz (2009), 1spir et al. (2009), Saraç (2013), Göçer and Hepkarş1 (2013), Özcan and Özçelebi (2013), Korkmaz (2014), Küçükaksoy et al. (2015) and Dura et al. (2017).

Dutt and Ghosh (1994), Shan and Sun (1998), Akbar and Naqvi (2000), Ahmed et al. (2000), Panas and Vamvoukas (2002), Sharma and Panagiotidis (2004), Dritsakis (2006), Chimobi (2010), Dreger and Herzer (2011), Teodora and Marinela (2011), Azharuddin and Paramanik (2014), Kumar (2015)'s research on the export-led growth hypothesis is not valid. Yiğidim and Köse (1997), Özmen and Furtun (1998), Karagöl and Serel (2005), Demirhan (2005), Taban and Aktar (2008), Takım (2010) and Agayev (2011), however, have concluded that export-led growth hypothesis is not valid in Turkey.

In the late 1980s, Paul M. Romer (1986) and Robert E. Lucas (1988) have established "Endogenous Growth Models" based on RandD and technology. These theories focus on the fact that economic growth can be positively affected by new technologies and new products that will emerge as a result of $R \& D$ activities. At this point, there are arguments that the return of export of especially new high-technology products to be obtained as a result of R\&D activities can contribute to economic growth. In this study, which investigates the effect of exports of the high-tech product on economic growth, we observed that there are a limited number of studies in the literature that support this relationship. The reason for this can be attributed to the fact that high-tech goods are often considered a product of R\&D activities. The fact that $R \& D$ expenditures are addressed as a whole in the literature, and the vast number of studies investigating the effects of $R \& D$ on economic growth seems to support this finding. The studies on the effect of high-technology product exports on economic growth are as follows:

In their study conducted by using the data from 45 developed and developing countries in the 1981-1997 period, Cuerasma and Wörz (2005) found that high technology product exports had a positive effect on economic growth.

Yoo (2008) has analysed the effects of high-technology product exports on economic production in his analysis conducted with 91 countries over the period of 1988-2000. The results show that high-technology product exports have a positive and significant contribution to economic growth. 
In his panel data analysis conducted with the 5-year averages data of the 1980-2004 period for 22 OECD countries, Falk (2009) investigated the effect of the change in the share of high technology product export on economic growth. In the results of the study, it has been found that high technology product exports had a significant effect on economic growth.

In their study carried out with the help of China data for the period 2002-2007, Sun \& Heshmati (2010) have found that high technology product export rates had a positive effect on total productivity.

Kılavuz and Topçu (2012) have used the method of panel data analysis with the 19982006 data for 22 developing countries, including Turkey, and investigated the relationship between high-tech product exports and economic growth. As a result of their study, it has been found that high-technology product exports had a positive and significant effect on economic growth.

Ustabaş and Ersin (2016) have conducted a study to determine the relationship between high-tech product exports and economic growth, using 1989-2014 data of Turkey and South Korea. As a result of the study, it has been concluded for South Korea that hightech exports of products had a short and long-term positive effect on economic growth. However, it has been found that this relationship is not valid for Turkey and only had a limited effect in the short term.

Y1ldiz (2017) has investigated the effects of high-tech product exports on economic growth using the 2005-2014 data from BRICS countries and Turkey. The results of the study have indicated that the increase in high-tech products export in BRICS countries and Turkey had a boosting effect on economic growth.

In their study investigating the relationship between high-technology product exports and economic growth using data from 14 OECD countries between 1989 and 2015, Kabaklarli et al. (2018) have found a long-term relationship between the two variables.

Considering the literature studies, it can be said that high technology product exports have positive effects on economic growth.

\section{MODEL AND DATA}

In this study that we investigated the relationship between Turkey's GDP and hightech product exports to Turkey, the data from the 1989-2016 period was used. The data of the variables were obtained from the World Bank's official website, and high-tech products include products of industries such as aerospace, computer, medicine, as well as scientific instruments and electrical machinery. The natural logarithm of the variables was taken to ensure the linearity of the series and flexible interpretation of the coefficients.

When performing a time series analysis, one should first determine whether the variables have time series characteristics. In this context, time-series graphs of the variables should be plotted, and time series components such as seasonality, trends, breaks, etc. should be examined. Graphs of variables are shown in Figure 1. 

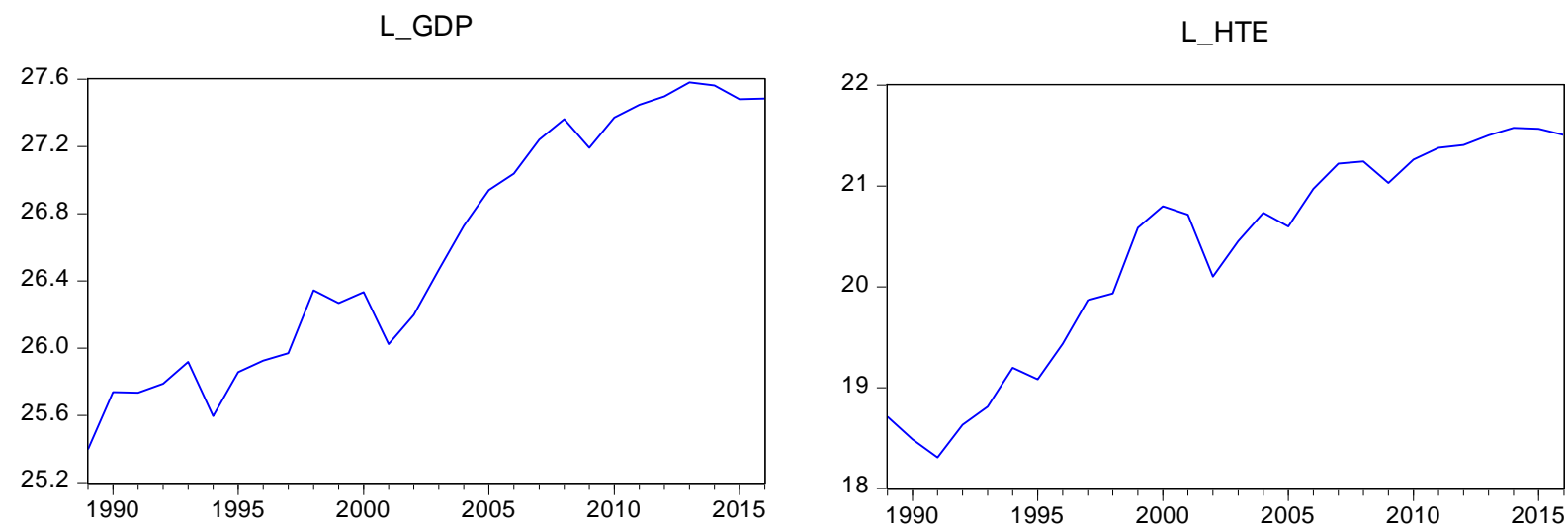

Figure 1. Graphs of Variables

When we look at Figure 1, it is noteworthy that there is an upward trend in both variables for the period addressed. It is considered that the current breaks are due to the effects of the economic and political developments of the period. This fact should not be ignored, and it is necessary to determine the periods in which the existing breaks were effective on the variables.

In the study, the relationships between variables were modelled as follows:

$$
L_{-} G D P_{t}=\beta_{0}+\beta_{1} L_{-} H T E_{t}+\alpha_{i} \text { Breaks }+u_{t}
$$

The dependent variable L_GDP in model 1 refers to the logarithmic GDP, and the independent variable L_HTE refers to the high technology product exports. The breaks variable refers to the dummy variables for the break dates obtained from the tests by Bai and Perron (2003), and $\alpha_{i}$ refers to the coefficient of the dummy variables. The $t$ index at the end of the variables indicates that the variables are a time series. $\beta_{0}$ refers to the constant term coefficient, and $\beta_{1}$ refers to the model's slope coefficient. $\beta_{1}$ refers to the change in $L_{G D P}$ induced by a $1 \%$ change in L_HTE. And, $u_{t}$ is the error term of the model.

\section{METHODOLOGY AND RESULTS}

In this study, which investigates the effect of high-tech product exports on economic growth, empirical correlations between variables were investigated in three stages. In the first stage, the significance of the breaks in Figure 1 in L_GDP, which is the dependent variable of the study, is statistically tested by using Bai and Perron $(2003)^{2}$ test. In the second stage, the steady-state levels of the variables were examined by the single-fracture ADF unit root test as carried out by Kirca and Topal (2017); and, in the third stage, the existence of long-term relationships between the variables were examined with the help of Bounds Testing based on Autoregressive Distributed Lag (ARDL) model.

When we look at Figure 1, we see that there are breaks in both variables for the studied period, and it is necessary to determine the periods, in which the existing breaks were effective on the variables. Since the dependent variable was L_GDP, only the break dates for this variable were investigated, and these dates were added to the ARDL model. Here, to determine the structural breaks, Bai and Perron (2003) structural breaks test was performed, and the test results were presented in Table1. 
Table 1. Bai \& Perron (2003) Test Results **

\begin{tabular}{|c|c|c|}
\hline \multicolumn{3}{|c|}{ L_GDP } \\
\hline Break test & Calculated statistics & $5 \%$ Critical values $* *$ \\
\hline 0 vs. $1 *$ & 21.95 & 11.47 \\
\hline 1 vs. 2 & 12.02 & 12.95 \\
\hline 2 vs. $3 *$ & 15.84 & 14.03 \\
\hline 3 vs. 4 & 4.32 & 14.85 \\
\hline 4 vs. 5 & 3.65 & 15.29 \\
\hline Indicates & number & significant \\
\hline
\end{tabular}

As shown in Table 1, there are significant structural breaks in L_GDP variable in 1994, 2001 and 2007. It is known that Turkey faced a severe economic crisis at these dates. Especially in 1994, the budget and current account deficit reached dramatic levels and the government's privatisation plans, which did not function as desired, caused the markets to narrow. With this process, the acceleration of capital outflows from the country led to a 14fold increase in the dollar exchange rate and exacerbated the crisis. The 2001 crisis, which has started with political tension in Turkey's National Security Council (NSC) in 2001, has been narrowed similarly with the 1994 crisis and exacerbated with capital outflows. The crisis started mainly in the banking sector, had an impact on the whole of the real sector. 2007, however, is the beginning of a global crisis of foreign origin. In particular, the impact of this economic crisis was being felt on a global scale in 2008, which affected Turkey slightly and indirectly.

In time series analysis, it is crucial to test the stationarity of the variables. This is because non-stationary variables cause the false regression problem in the regression analysis to be performed with these variables. False regression is, in a sense, false correlations. For this reason, many unit root tests have been developed to test the stationarity. In this study, it was aimed to determine the degree of integration of the variables using single-break unit root test. Table 2 shows the results of the single-break ADF unit root test for the variables used in the study.

Table 2. Single-Break ADF Unit Root Test*

\begin{tabular}{|c|c|c|c|}
\hline Variable & Calculated t-statistics value & Probability value & Date of break \\
\hline L_GDP & -2545 & 0.935 & 2007 \\
\hline$\Delta$ L_GDP & $\mathbf{- 5 . 8 0 4} * *$ & $\mathbf{0 . 0 0 1}$ & $\mathbf{2 0 0 7}$ \\
\hline L_HTE & -0.356 & 0.998 & 2001 \\
\hline$\Delta$ L_HTE & $\mathbf{- 9 . 6 8 0} * *$ & $\mathbf{0 . 0 0 1}$ & $\mathbf{2 0 0 1}$ \\
\hline
\end{tabular}

* The unit root test was performed in constant and trend models by taking into account the breaks.

** Expresses stationarity according to $1 \%$ level of significance.

According to the results of the single-break ADF unit root test in Table 2, both variables become stationary at the $1 \%$ level of statistical significance if the first differences I(1) are taken. Also, it was found that there were breaks for the L_GDP variable in 2007, and 
the L_HTE in 2001. Existing breaks corresponded to the global crisis starting in 2007 and felt in 2008, and the 2001 crisis, which has started with political tension in Turkey's National Security Council (NSC) and reflected on the entire economy, which already has narrow.

ARDL Bounds Testing, developed by Pesaran et al. (2001), is a method developed to examine the long periods between variables. The most important advantage of this test compared to the other cointegration tests is that it allows the analysis of long-term relationships between the variables that are stationary at different levels. In other words, some of the variables can be I(1), and others can be I(0). However, one of the most important conditions that should be known here is that the dependent variable should be I(1); and the second one is that any of the variables should not be stationary higher-order than I(1).

ARDL models allow the inclusion of both the dependent variables and the delays of the independent variables in the same model. In model 2, an equation for the ARDL model we created by using our variables is shown. $\theta \mathrm{s}$ in the model show the coefficient matrix of the independent variables. The terms $m, n$ and $l$ refer to the different delay values that the variables can take. $i$ refers to the delay number. And, $e_{t}$ is the error term of the model. The delay numbers in model 2 are determined with the help of various information criteria. In this study, it was determined by Akaike Information Criterion (AIC). Besides, the breaks determined in the L_GDP variable were added to the ARDL model as an exogenous variable for analysis.

$$
L_{-} G D P_{t}=\theta_{0}+\sum_{i=1}^{m} \theta_{1 i} L_{-} G D P_{t-i}+\sum_{i=0}^{n} \theta_{2 i} L_{-} H T E_{t-i}+\alpha_{i} \text { Breaks }+e_{t}
$$

As a result of the analysis, it was determined that the ARDL $(1,0)$ model was a suitable model. It is essential in the test that this model is suitable. For this, descriptive tests were performed to test whether there were any problems in the model. As seen in Table 3, it is seen that there is no autocorrelation and heteroscedasticity problems in the ARDL (1.0) model, the error terms have a normal distribution and that there is no distress in the functional form of the model.

Table 3. ARDL(1,0) Model Prediction

\begin{tabular}{lcccc}
\hline \multicolumn{1}{c}{ Variable } & Coefficient & Standard error & t-statistics & Probability \\
\hline L_GDP(-1) & $0.782^{*}$ & 0.084 & 9305 & $\mathbf{0 . 0 0 1}$ \\
L_HTE & 0.095 & 0.058 & 1638 & 0.116 \\
D2001 & $-0.494^{*}$ & 0.124 & -3961 & $\mathbf{0 . 0 0 1}$ \\
D2007 & 0.103 & 0.088 & 1172 & 0.254 \\
D1994 & $-0.450^{*}$ & 0.122 & -3693 & $\mathbf{0 . 0 0 1}$ \\
C & $3.925^{*}$ & 1229 & 3192 & $\mathbf{0 . 0 0 4}$ \\
\hline \multicolumn{5}{c}{ Descriptive statistics } \\
\hline \multicolumn{5}{c}{ Calculated statistics } \\
\hline Breusch-Godfrey Autocorrelation & 0.762 \\
Breusch-Pagan-Godfrey Test & 6408 & Probability \\
Jargue-Bera Test of Normality & 0.585 & 0.683 \\
Ramsey RESET Test & 0.716 & 0.268 \\
\hline
\end{tabular}

* Expresses significance according to the $5 \%$ level of significance. 
The analysis of whether the coefficients obtained by the ARDL $(1,0)$ model are stable during the examined period was performed with the help of CUSUM and CUSUMQ analysis. When we look at Figure 2, it is seen that the coefficients obtained in the period analysed for the ARDL $(1,0)$ model are stable. This is because CUSUM and CUSUMQs obtained are within $5 \%$ confidence interval.

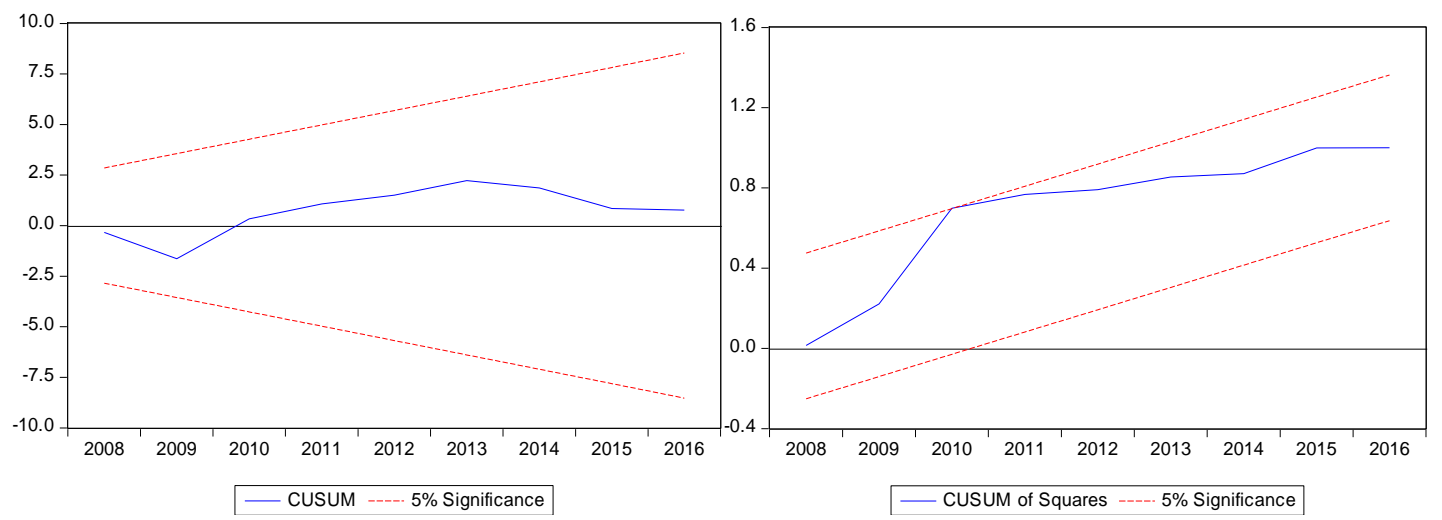

Figure 2. CUSUM ve CUSUMQ Results

After determining the ARDL model, the equation to be used in the bounds testing was formed. Equation 3 shows the equation used in the bounds testing. Using this equation, longterm relationships between variables were tested.

$$
\begin{aligned}
\Delta L_{-} G D P_{t}= & \theta_{0} \\
& +\sum_{i=1}^{m} \theta_{1 i} \Delta L_{-} G D P_{t-i} \\
& +\sum_{i=0}^{n} \theta_{2 i} \Delta L_{-} H T E_{t-i}+\theta_{3} L_{-} G D P_{t-i}+\theta_{4} L_{-} H T E_{t-i}+\alpha_{i} \text { Breaks }+e_{1 t}
\end{aligned}
$$

In order to test the long-term relationships between variables, the following hypotheses were established for the ARDL bounds testing:

$$
\begin{aligned}
& H_{0}: \theta_{3}=\theta_{4}=0 \text { (no cointegration), } \\
& H_{1}: \theta_{3} \neq 0 \text { or } \theta_{4} \neq 0 \text { (cointegration). }
\end{aligned}
$$

The hypotheses were tested using Wald F statistics. In other words, a Wald F test was used to test whether $\theta_{3}=\theta_{4}=0$ coefficients are equal to zero in the model to obtain statistics on the bounds testing. This statistical value obtained in order to decide on hypotheses was compared with the lower limit I(0) and upper limit I(1) values, obtained from the study by Pesaran et al. (2001:300). If the calculated statistical value is higher than the critical value $\mathrm{I}(1)$, then $\mathrm{H} 0$ is not rejected, leading to conclusion that there is a long-term relationship between the variables.

Table 4. ARDL Bounds Testing Results

\begin{tabular}{cccc}
\hline $\mathbf{K}$ & F-statistic & \multicolumn{2}{c}{$\mathbf{1 \%}$ Critical values } \\
\cline { 3 - 4 } 1 & & $\mathrm{I}(0)$ & $\mathrm{I}(1)$ \\
\cline { 3 - 4 } & $\mathbf{1 0 . 9 0 5 *}$ & 4.94 & 5.58 \\
\hline
\end{tabular}

Table 4 shows the ARDL bounds testing results. According to these results, $H_{0}$ hypothesis is rejected because the F statistic value (4.94) obtained is higher than the critical 
value I(1) (5.58). This means that the L_HTE variable affects the L_GDP variable in the long term. Taking this finding into consideration, it can be said that high technology product exports have an effect on GDP in the long term. After this stage, it should be determined whether the error correction mechanism works, as well as determining the extent and direction of effect of independent variables on the dependent variables in the long and short term. Also, it should be tested whether the independent variables have a statistically significant effect on the dependent variable. The error correction mechanism is tested employing the model no. 4.

$\Delta L \_G D P_{t}=\theta_{0}+\sum_{i=1}^{m} \theta_{1 i} \Delta L_{-} G D P_{t-i}+\sum_{i=0}^{n} \theta_{2 i} \Delta L_{-} H T E_{t-i}+\theta_{3} E C M_{t-1}+e_{2 t}$

A statistically significant $\operatorname{ECM}(-1)$ coefficient in model 4 in the range of 0 to -1 indicates that the imbalances between the variables are improved in the short term. Table 5 shows error correction model results. Besides, short-term and long-term coefficients can also be found in this table. According to these results, $\operatorname{ECM}(-1)$ coefficient is between 0 and -1 , and it is statistically significant. This shows that the short-term deviations in the model have reached an equilibrium in the long term.

Table 5. Short-Term and Long-Term Coefficients

\begin{tabular}{|c|c|c|c|c|}
\hline \multicolumn{5}{|c|}{ Short-term coefficients and error correction model } \\
\hline Variable & Coefficient & Standard error & t-statistics & Probability \\
\hline$\Delta \mathrm{L} \_\mathrm{HTE}$ & -0.047 & 0.088 & -0.535 & 0.597 \\
\hline$\Delta \mathrm{D} 2001$ & $-0.473 *$ & 0.084 & -5600 & 0.001 \\
\hline$\Delta D 2007$ & $0.229 *$ & 0.077 & 2978 & 0.007 \\
\hline$\Delta \mathrm{D} 1994$ & $-0.471 *$ & 0.08 & -5842 & 0.001 \\
\hline ECM(-1) & $-0.243 *$ & 0.047 & -5178 & 0.001 \\
\hline \multicolumn{5}{|c|}{ Long-term coefficients } \\
\hline Variable & Coefficient & Standard error & t-statistics & Probability \\
\hline L_HTE & $0.440 *$ & 0.13 & 3377 & 0.002 \\
\hline D2001 & $-2.274 *$ & 0.895 & -2539 & 0.019 \\
\hline D2007 & 0.475 & 0.44 & 1080 & 0.292 \\
\hline D1994 & $-2.073 *$ & 1013 & -2045 & 0.053 \\
\hline C & $18.056 *$ & 2769 & 6519 & 0.001 \\
\hline
\end{tabular}

* Expresses significance according to the $5 \%$ level of significance.

If we look at Table 5, there is no statistically significant relationship between L_HTE and L_GDP in the short term, but it has a statistically significant effect on the L_GDP variable in the long term. A $1 \%$ increase in the L_HTE variable in the long term increases the L_GDP variable by approximately $0.44 \%$. This means that changes in high-technology product exports have a significant impact on economic growth in the long run. As mentioned above, a $1 \%$ increase in high technology product exports increases economic growth by approximately $0.44 \%$ in the long term. 


\section{CONCLUSION}

In this study, which investigates the effect of exports of the high-tech product on economic growth, long-term relationships were found between the variables according to the results of the ARDL bounds testing. This means that high-tech product exports affect economic growth in the long term. In addition, a $1 \%$ increase in high-tech product exports increases economic growth by approximately $0.44 \%$ in the long term. Similar to other studies in the literature, it has been concluded that exports of high-tech products affect economic growth positively in Turkey.

In countries such as South Korea and Singapore, which are growing fast in recent years by overcoming the middle-income trap, the driving force behind economic growth is higher value-added knowledge and the ability to produce technologically advanced products (Tsunekawa and Todo, 2019:5). According to 2016 data published in the World Bank official website, the ratio of high-tech export products were $26.6 \%$ in South Korea, $48.9 \%$ in Singapore, $2 \%$ in Turkey. As is seen, Turkey's share of such products is very small when the types of exported products of these example countries were compared with that of Turkey. As can be understood from all these, developing countries such as Turkey need to increase the rate of high-tech products in goods subject to export, to achieve stable economic growth and to maintain their competitive advantages in the international market. To achieve these gains, R\&D activities should be encouraged, especially in such countries, and public sector, private sector and universities should work in cooperation in this regard.

\section{REFERENCES}

Abou-Stait, F. (2005). Are Exports the Engine of Economic Growth? An Application of Cointegration and Causality Analysis for Egypt, 1977-2003. African Development Bank Economic Research Working Paper, No 76.

Abual-Foul, B. (2004). Testing The Export-Led Growth Hypothesis: Evidence from Jordan. Applied Economics Letters, 11, 393-396.

Agayev, S. (2011). Relationship between Export and Economic Growth: Panel Cointegration and Panel Causality Analysis in 12 Transition Economies Case. Ege Akademik Bakis, 11(2), 241-254.

Ahmed, Q. M., Butt, M.S. \& Alam, S. (2000). Economic Growth, Export, and External Debt Causality: The Case of Asian Countries. The Pakistan Development Review, 39(4), 591-608.

Akbar, M. \& Naqvi, Z.F. (2000). Export Diversification and the Structural Dynamics in the Growth Process: The Case of Pakistan. The Pakistan Development Review, 39(4), 573589.

Al-Yousif, Y. K. (1999). On The Role Exports in The Economic Growth of Malaysia: A Multivariate Analysis. International Economic Journal, 13(3), 67-75.

Anwer, M. S. \& Sampath, R. K. (2000). Exports and Economic Growth. Indian Economic Journal, 47(3), 79-88.

Awokuse, T.O. (2003). Is the Export-led Growth Hypothesis Valid for Canada?. Canadian Journal of Economics, 36(1), 125-136.

Azharuddin, S. M. \& Paramanik, R. N. (2014). Revisiting Growth-Export Nexus of Indian Economy. Asian Journal of Research in Social Sciences and Humanities, 4(4), 61-73. 
Bahmani-Oskooee, M. \& Alse, J. (1993). Export Growth and Economic Growth: An Application of Cointegration and Error-Correction Modelling. The Journal of Developing Areas, 27, 535-542.

Bahmani-Oskooee, M. \& Niroomand, F. (1999). Openness and Economic Growth: An Empirical Investigation. Applied Economic Letters, 6, 557-561.

Baumol, W. J. (2002). The Free-Market Innovation Machine: Analyzing The Growth Miracle of Capitalism. Princeton, N.J.: Princeton University Press.

Bilgin, C. \& Şahbaz, A. (2009). Causality Relations between Growth and Export in Turkey. Gaziantep University Journal of Social Sciences, 8(1), 177-198.

Chimobi, O.P. (2010). The Estimation of Longrun Relationship between Economic Growth, Investment and Export in Nigeria. International Journal of Business and Management, 5(4), 215-222.

Cuerasma, J. C. \& Wörz, J. (2005). On Export Composition and Growth. Review of World Economics, 141(1), 33-49.

Demirhan, E. (2005). The Causality Relationship between Growth and Export: The Case of Turkey. Ankara Üniversity SBF Journal, 60(4), 75-88.

Doraisami, A. (1996). Export Growth and Economic Growth: A Re-examination of Some Time Series Evidence of the Malaysian Experience. The Journal of Developing Areas, 30, 223-230.

Dreger, C. \& Herzer, D. (2011). A Further Examination of the Export-Led Growth Hypothesis. DIW Berlin German Institute for Economic Research, Discussion Papers, 1149, 1-39.

Dritsakis, N. (2006). Exports and Economic Growth: An Empirical Investigation of EU, USA and Japan Using Causality Tests. International Review of Applied Economic ResearchNew Delhi, 1(2), 181-194.

Dura, Y. C., Beşer, M. K., \& Acaroğlu, H. (2017). Econometric Analysis of Turkey's ExportLed Growth. Ege Academic Review, 17(2), 295-310.

Dutt, S. \& Ghosh, D. (1994). An Empirical Investigation of the Export Growth-Economic Growth Relationship. Applied Economics Letters, 1(3), 44-48.

Ekanayake, E.M. (1999). Export and Economic Growth in Asian Developing Countries: Cointegration and Error Correction Models. Journal of Economic Development, 24 (2), 43-56.

Elbeydi, K. R.M., Hamuda, A. M. \& Gazda, V. (2010). The Relationship between Export and Economic Growth in Libya Arab Jamahiriya. Theoretical and Applied Economics, 17(1), 69-76.

Eusuf, M. A. \& Ahmed, M. (2007). Causality between Export and Growth: Evidence from South Asian Countries. MPRA Paper No. 21027.

Falk, M. (2009). High-Tech Exports and Economic Growth in Industrialized Countries. Applied Economics Letters, 16 (10), 1025-1028.

Ghatak, S., Milner, C. \& Utkulu, U. (1997). Exports, Export Composition and Growth: Cointegration and Causality Evidence for Malaysia. Applied Economics, 29, 213-223.

Göçer, İ. \& Hepkarş1, N. (2013). Relationship of Export-Growth: An Analysis with Structural Breaks. Siyaset, Ekonomi ve Yönetim Araştırmalar Dergisi, 1(4), 57-87. 
Grossman, H. (1991). Trade, Innovation and Growth. American Economic Review, 80, 86-91.

Halıcıoğlu, F. (2007). A Multivariate Causality Analysis of Export and Growth for Turkey. MPRA Paper No. 3565.

Istaiteyeh, R.M.S. \& Ismail, M.T. (2015). A Causal Relationship Between Foreign Direct Investment, Economic Growth and Export: Empirical Case for Jordan. Advances in Management \& Applied Economics, 5(4), 19-30.

Ispir, M.S., Açıkgöz Ersoy, B. \& Yılmazer, M. (2009). Does Export or Import More Effective on Turkish Growth Dynamics?. Dokuz Eylül Üniversitesi İktisadi ve İdari Bilimler Fakültesi Dergisi, 24, 59-72.

Jarra, S.T. (2013). Exports, Domestic Demand and Economic Growth in Ethiopia: Granger Causality Analysis. Journal of Economics and International Finance, 5(9), 357-372.

Kabaklarlı, E., Duran, M. S., \& Üçler, Y. (2018). High-Technology Exports and Economic Growth: Panel Data Analysis for Selected OECD Countries High-Technology Exports and Economic Growth: Panel Data Analysis for Selected OECD Countries. In Forum Scientiae Oeconomia, 6(2), 47-60.

Karagöl, E. \& Serel, A. (2005). Türkiye'de İhracat ve GSMH Arasındaki İlişkinin Kointegrasyon Yöntemiyle İncelenmesi. İstanbul Üniversitesi İktisat Fakültesi Sosyal Siyaset Konferansları Dergisi, 50, 1029-1040.

Kavoussi, R.M. (1984). Export, Expansion and Economic Growth. Journal of Development Economics, 14(2), 241-250.

Keong, C. C., Yusop, Z. \& Liev, V. K. (2003). Export-led Growth Hypothesis in Malaysia: An Application of Two Stage Least Square Technique. International Finance Econ WPA No. 0308002.

Kilavuz, E. \& Topcu, B. A. (2012). Export and Economic Growth in The Case of the Manufacturing Industry: Panel Data Analysis of Developing Countries. International Journal of Economics and Financial Issues, 2(2), 201-215.

Kirca, M. \& Topal, M.H. (2017). An Analysis of The Impact of Tourism Demand on Tax Revenues in Turkey. Balkan and Near Eastern Journal of Social Sciences, 3(2), 96-108.

Kızılgöl, Ö. (2006). Türkiye'de İhracata ve Turizme Dayalı Büyüme Hipotezinin Analizi: Eşbütünleşme ve Nedensellik İlişkisi. Akademik Baklş, 10, 1-19.

Korkmaz, S. (2014). Türkiye Ekonomisinde İhracat ve Ekonomik Büyüme Arasındaki Nedensellik İlişkisi. Business and Economics Research Journal, 5(4), 119-128.

Kumar, G. (2015). Export-Led-Growth Hypothesis: Further Econometrics Evidence from India. Economic Affairs, 60(2), 197-205.

Küçükaksoy, I., Çifçi, I. \& Özbek, R. I. (2015). Export-led Growth Hypothesis: Turkey Application. Çankırl Karatekin University Journal of The Faculty of Economics and Administrative Sciences, 5(2), 691-720.

Kwan, A.C.C. \& B. Kwok (1995). Exogenity and the Export-led Growth Hypothesis: The Case of China. Southern Economic Journal, 61(8), 1158-1166.

Lucas, R. E. (1988). On The Mechanics of Economic Development. Journal of Monetary Economics, 22(1), 3-42.

Mamun, K. A. \& Nath, H. K. (2005). Export-led Growth in Bangladesh: A Time Series Analysis. Applied Economics Letters, 12, 361-364. 
Medina-Smith, E.J. (2001). Is the Export-Led Growth Hypothesis Valid for Developing Countries? A Case Study of Costa-Rica. Policy Issues in International Trade and Commodities Study Series, 7, United Nations Conference on Trade and Development.

Özcan, B. \& Özçelebi, O. (2013). Is Export-Led Growth Hypothesis Applicaple To Turkey?. Yönetim ve Ekonomi: Celal Bayar Üniversitesi Iktisadi ve İdari Bilimler Fakültesi Dergisi, 20(1), 1-14.

Özmen, E., \& Furtun, G. (1998). Export-Led Growth Hypothesis and The Turkish Data: An Empirical Investigation. METU Studies in Development, 25(3), 491-503.

Panas, E., \& Vamvoukas, G. (2002). Further Evidence on The Export-Led Growth Hypothesis. Applied Economics Letters, 9(11), 731-735.

Pandey, A. K. (2006). Export and Economic Growth in India: Causal Interpretation. MPRA Paper No. 14670.

Pesaran, M. H., Shin, Y. \& Smith, R. J. (2001). Bounds Testing Approaches to The Analysis of Level Relationships. Journal of Applied Econometrics, (16), 289-326.

Ramos, F. F. R. (2001). Exports, Imports, and Economic Growth in Portugal: Evidence from Causality and Cointegration Analysis. Economic Modelling, 18(4), 613-623.

Rivera-Batiz, L.A. \& Romer, P.M. (1991). Economic Integration and Endogenous Growth. Quarterly Journal of Economics, 106, 531-555.

Romer, P. M. (1986). Increasing Returns and Long-Run Growth. The Journal of Political Economy, 95(5), 1002-1037.

Romer, P. M. (1990). Endogenous Technological Change. The Journal of Political Economy, 98(5), 71-102.

Saleem, A. \& Sial, M.H. (2015). Exports-Growth Nexus in Pakistan Cointegration and Causality Analysis. Pakistan Economic and Social Review, 53(1), 17-46.

Saraç, T.B. (2013). İhracat ve İthalatın Ekonomik Büyüme Üzerindeki Etkisi: Türkiye Örneği. Ege Academic Review, 13(2), 194-181.

Sengupta, J.K. \& Espana, J.R. (1994). Exports and Economic Growth in Asian NICs: An Econometric Analysis for Korea. Applied Economics, 26, 41-51.

Serletis, A. (1992). Export Growth and Canadian Economic Development. Journal of Development Economics, 38(1), 133-145.

Shan, J. \& Sun, F. (1998). On The Export-Led Growth Hypothesis: The Econometric Evidence from China. Applied Economics, 30(8), 1055-1065.

Sharma, A. \& Panagiotidis, T. (2005). An Analysis of Exports and Growth in India: Cointegration and Causality Evidence (1971-2001). Review of Development Economics, 9(2), 232-248.

Shirazi, N. S. \& Manap, T. A. A. (2005). Export-Led Growth Hypothesis: Further Econometric Evidence from South Asia. The Developing Economies, 43(4), 472-88.

Solow, R. M. (1956). A Contribution to the Theory of Economic Growth. The Quarterly Journal of Economics, 70(1), 65-94.

Solow, R. M. (1957). Technical Change and the Aggregate Production Function. The Review of Economics and Statistics, 39(3), 312-320. 
Sylwester, K. (2001). R\&D and Economic Growth. Knowledge, Technology, \& Policy, 13(4), 71-84.

Taban, S. \& Aktar, I. (2008). An Empirical Examination of the Export-Led Growth Hypothesis in Turkey. Journal of Yasar University, 3(11), 1535-1551.

Takım, A. (2010). The Relationship Between GDP and Exports in Turkey: Granger Causality Test. Atatürk Üniversitesi Sosyal Bilimler Enstitüsü Dergisi, 14(2), 1-16.

Teodora, M.I. \& Marinela, S.R. (2011). An Investigation of Longrun Relationship Between Economic Growth, Investment and Export in Romania. Annals of Faculty of Economics, 1(1), 316-321.

Türedi, S. (2013). The Impact of Information and Communication Technologies to Economic Growth: Panel Data Analysis for Developed and Developing Countries. Gümüşhane University Journal of Social Sciences Institute, 4(7), 298-322.

Tsunekawa, K. \& Todo, Y. (2019). Emerging Challenges for Emerging States. In Emerging States at Crossroads, Singapore: Springer, 1-23.

Tyler, W. (1981). Growth and Export Expansion in Developing Countries: Some Empirical Evidence. Journal of Development Economics, 19(2), 121-130.

Ullah, S., Zaman, B., Farooq, M. \& Javid, A. (2009). Cointegration and Causality Between Exports and Economic Growth in Pakistan. European Journal of Social Sciences, 10(2), 264-272.

Ustabaş, A. \& Ersin, Ö. Ö. (2016). The Effects of R\&D and High Technology Exports on Economic Growth: A Comparative Cointegration Analysis for Turkey and South Korea. In International Conference On Eurasian Economies, 44-55.

Vohra, R. (2001). Export and Economic Growth: Further Time Series Evidence from LessDeveloped Countries. International Advances in Economic Research (IAER), 7(3), 345350 .

Yardımcıoğlu, F. \& Gülmez, A. (2013). Export and Economic Growth in Turkish Republics: A Panel Cointegration and Causality Analysis. The Journal of Knowledge Economy \& Knowledge Management, 8(1), 145-161.

Yıldız, Ü. (2017). Panel Data Analysis of The Relationship Between Hightechnology Export and Economic Growth for BRICS Countries and Turkey. Dumlupinar University, Journal of Social Sciences, 53, 26-34.

Yiğidim, A. \& Nezir, K. (1997). İhracat ve Ekonomik Büyüme Arasındaki İlişki, İthalatın Rolü: Türkiye Örneği (1980-1996). Ekonomik Yaklasim, 8(26), 71-85.

Yoo S.H. (2008): High-Technology Exports and Economic Output: An Empirical Investigation. Applied Economics Letters, 15(7), 523-525. 